\title{
PROFESI KEGURUAN SEBAGAI GURU INDONESIA
}

Akhlada El Hasanah

\author{
Email: 2010128220015@mhs.ulm.ac.id \\ Program Studi Pendidikan IPS Fakultas Keguruan dan Ilmu Pendidikan \\ Universitas Lambung Mangkurat \\ Banjarmasin
}

\begin{abstract}
Abstrak
Dalam artikel ini bertujuan untuk mengetahui tentang konsep profesi, profesi guru untuk memberikan pengetahuan tentang pekerjaan dalam bentuk sebuah profesi. Guru dapat digolongkan/diklasifikasikan sebagai sebuah profesi. Profesi guru mempunyai peran, hak, dan kewajiban sebagai seorang guru. Indonesia memerlukan adanya profesionalisme seorang guru untuk memajukan pendidikan Indonesia. Guru yang profesional akan berdampak lebih baik bagi peningkatan mutu pendidikan. Komponen kompetensi guru dalam pendidikan Indonesia juga harus dimiliki seorang guru agar guru dapat disebut sebagai guru yang profesional.
\end{abstract}

Kata kunci : Konsep profesi guru, professional guru, komponen kompetensi guru, professionalisme guru, peran guru hak guru dan kewajiban guru.

\section{PENDAHULUAN}

Profesi biasanya pada lingkungan masyarakat sering diartikan sebagai suatu pekerjaan atau jabatan seseorang. Dapat di tunjukkan profesi itu seperti sebuah pekerjaan yang memiliki syarat-syarat tertentu, dalam syarat tersebut dapat digolongkan menjadi suatu profesi yang pasti memiliki spesialisasi ilmu dan tidak sembarang orang dapat bekerja di suatu bidang profesi jika tidak memiliki latar belakang keilmuan yang relevan.

Masyarakat ada yang berspekulasi atau menganggap bahwa semua pekerjaan itu adalah profesi. Padahal tidak semua pekerjaan dapat dikatakan sebagai sebuah profesi, bahkan masyarakat ada yang menganggap bahwa penyanyi, artis, pedagang, pengamen dan lainnya sebuah bentuk dari profesi. Nyatanya tidak semua pekerjaan atau tugas yang dilakukan oleh seseorang dapat dikatakan sebagai profesi.

Menurut Sanusi, dkk (1991:19) menjelaskan konsep profesi adalah suatu jabatan atau pekerjaan yang menuntut keahlian (experties) dari para anggotanya. Yang artinya, ialah tidak bisa dilakukan oleh sembarang orang yang tidak dilatih dan tidak disiapkan secara khusus untuk melakukan pekerjaan itu. Keahlian pun diperoleh memalui profesionalisasi, yang 
dimana dilakukan baik sebelum seseorang menjalani profesi itu (pendidikan/latihan prajabatan) mamupun setelah mejalani suatu profesi (in-service training). Profesi yang tepat pada seseorang itu seperti contohnya bekerja sebagai seorang guru, dokter, dan lainnya. Sebab pekerjaan-pekerjaan tersebut pasti memerlukan keahlian khusus di bidangnya. Jadi profesi dapat diartikan sebagai suatu bidang pekerjaan yang didasarkan pada keahlian tertentu.

Secara umum ciri-ciri profesi menurut (R.Rizal Isnanto : 2009) yang selalu melekat pada profesi ialah sebagai berikut:

1. Adanya pengetahuan khusus, pada keahlian dan keterampilan ini dimiliki dari pendidikan, pelatihan dan pengalaman yang bertahun-tahun.

2. Adanya kaidah dan standar moral yang sangat tinggi. Yang di mana setiap pelaku profesi mendasarkan kegiatannya pada kode etik profesi.

3. Mengabdi pada kepentingan masyarakat, yang artinya pada setiap pelaksaan profesi harus meletakkan kepentingan pribadi di bawah kepentingan masyarakat.

4. Ada izin khusus untuk menjalankan suatu profesi. Semua profesi akan berkaitan dengan kepentingan masyarakat, nilai-nilai kemanusiaan berupa keselamatan, keamanan, kelangsungan hidup dan lain sebagainya, maka dari itu untuk menjalankan profesi terlebih dahulu ada izin hsus.

5. Kaum profesional biasanya menjadi seorang anggota dari suatu profesi.

Secara umum syarat suatu pekerjaan untuk dapat digolongkan menjadi suatu profesi yaitu, memiliki spesialisasi ilmu, memiliki kode etik dalam menjalankan profesi, memiliki organisasi profesi, diakui oleh masyarakat, sebagai panggilan hidup, dilengkapi kecakapan diagnostik, dan mempunyai klien yang jelas (Bambang Subiyakto \& Helmi Akmal, 2020: 14).

Pada konsep profesi guru, guru yang profesional harus memiliki komitmen dan tidak boleh goyah oleh selera masyarakat, sebab tugas seorang guru untuk peserta didiknya ialah membantu peserta didik untuk belajar, membantu dan membimbing peserta didik dalam belajar. Menurut Asyad dan Salahudin (2018) belajar merupakan cara seseorang untuk mendapatkan prestasi agar mampu melakukan sesuatu. Seorang guru atau dosen memang tidak di salahkan untuk menyenangkan peserta didik dan mungkin orang tua mereka. Namun demikian, tetap harus diingat bahwa tugas profesional seorang pendidik adalah membantu peserta didik belajar, yang bahkan terlepas dari persoalan apakah mereka suka atau tidak suka. Seorang peserta didik professional harus mampu memberikan yang terbaik kepada peseta didik, sebagai tujuan utama menjalankan tugasnya. 
Pada konsep profesionalitas guru, profesionalitas tidak hanya sebagai profesi saja, tetapi bisa sebagai suatu tugas kemanusiaan dan kemasyarakatan yang berkaitan dengan profesionalotasnya yang meliputi mengajar, mendidik, dan melatih. Dengan tugas tersebut maka guru harus mempunyai banyak peran seperti sebagai fasilitator, inspirator, korektor, pembimbing, dan lain sebagainya.

\section{PERAN GURU SEBAGAI SEBUAH PROFESI}

Guru dapat digolongkan sebagai sebuah profesi, sebab menjadi guru dituntut memiliki keahlian yang di mana akan di dapat melalui pendidikan dan latihan. Profesi guru juga memiliki jabatan yang memerlukan keahlian khusus sebagai guru dan tidak dapat dilakukan oleh sebagian orang diluar sana. Oleh karena itu, menjadi seorang guru tentu memiliki syarat-syarat di bidang spesialis ilmu dan tentunya memiliki kode etik jabatan. Menjadi seorang guru memerlukan persiapan dalam pendidikan dan pelatihan secara khusus, jadi guru dapat digolongkan sebagai profesi.

Dalam Undang-Undang No. 14 Tahun 2005, dapat di katakan bahwa guru adalah pendidik yang profesional dengan tugas utamanya ialah mendidik, megajar, membimbing, mengarahkan, melatih, menilai, dan mengevaluasi peserta didik. Guru dapat diartikan sebagai orang yang memiliki tugas yang beterkaitan dengan mengupayakan mencerdasakan kehidupan bangsa dalam aspeknya, baik spritual dan emosional, intelektual, fisikal, maupun aspek lainnya (Bambang Subiyakto \& Helmi Akmal, 2020: 37). Menruut Undang-Undang No.14 Tahun 2005 tentang guru dan dosen, bahwa guru wajib memiliki kualifikasi akademik, kompetensi, sertifikat pendidik, sehat jasmani dan rohani, serta wajib memiliki kemampuan untuk mewujudukan tujuan pendidikan nasional.

Peran guru ialah mengajarkan pendidikan. Salah satunya guru adalah sebagai motivator belajar untuk peserta didik, dalam dunia pendidikan motivasi selalu menjadi faktor yang dominan dalam ikut menentukan tercapainya atau tidaknya suatu tujuan pembelajaran. Dalam proses belajar dan pembelajaran motivasi sangat penting bagi keberhasilan siswa. Sebab dengan adanya motivasi dari guru untuk siswa maka siswa akan dapat termotiviasi apa yang akan ia lakukan untuk mempersiapkan dirinya dalam belajar atau menghadapi ujian (Dimyanti, 1999:80). Oleh karena itu, peran seorang guru sangat diperlukan bagi peserta didik. Yang dimana peran seorang guru tidak hanya semata-mata mentransfer ilmu nya kepada siswa, tetapi guru juga sebagai motivator bagi siswa agar siswa memiliki prestasi dalam belajar, sebab siswa yang memiliki motivasi akan mencapai hasil belajar yang baik dan lebih tinggi dari pada siswa yang sebaliknya yang tidak memiliki motivasi.

Guru sebagai sebuah profesi di bidang pendidikan yang memiliki hak dan kewajiban yang menyangkut dunia pendidikan yang digeluti. Hak-hak guru merupakan apa saja yang di 
dapatkan oleh seseorang yang memiliki profesi guru, dan kewajiban guru adalah apa saja yang dilaksanakan seorang guru dalam menjalankan profesinya. Hak dan kewajiban guru dalam UU No. 14 Tahun 2005 tentang guru dan dosen sehingga setiap guru mendapatkan perlindungan terhadap hak yang dimiliki dan kewajiban yang harus dilaksanakan.

Dalam menjalankan tugas dan profesinya, seorang guru memiliki hak dan kewajiban yang harus diterapkan dan diperhatikan. Hak guru berarti suatu yang harus didapatkan oleh seorang guru setelah ia melaksanakan sejumlah kewajibannya sebagai guru. Sedangkan kewajiban guru adalah sesuatu yang harus patut dilaksanakan oleh guru dalam menjalankan profesinya. Hak dan kewajiban guru sebagai pendidik di atur dalam peraturan perundangundangan yang berkaitan dengan pendidikan. Dalam UU No. 14 Tahun 2005 tentang guru dan dosen, pada bagian kedua mengenai hak dan kewajiban pasal 14 (Bambang Subiyakto \& Helmi Akmal, 2020:44).

Ada beberapa hak yang perlu dimiliki seorang guru sebagai berikut :

1. Mendapatkan atau memperoleh penghasilan dari atas kewajibannya dalam mengajar untuk kebutuhan hidup dan jaminan kesejahteraan sosial.

2. Mendapatkan perlindungan dalam melaksanakan tugas dan hak atas kekayaan intelektual.

3. Memiliki kebebasan untuk berserikat dalam organisasi profesi.

4. Memiliki kesempatan untuk berperan dalam menentukan kebijakan pendidikan.

5. Memperoleh pelatihan dan pengembangan profesi dalam bidangnya.

Jadi dapat diketahui bahwa hak guru dalam menjalankan profesinya meliputi hak hidup, hak perlindungan karir, hak kebebasan intelektual, hak berpendapat, hak berserikat, dan hak pengembangan karir. Dalam berbagai hak tersebut dapat membuat guru merasa aman dalam menjalankan profesinya dan dapat berkonstribusi maksimal dalam memajukan pendidikan nasional (Bambang Subiyakto \& Helmi Akmal, 2020:47).

Kewajiban guru ialah memberikan pendidikan kepada peserta didik. Dalam melaksanakan tugas keprofesionalan dalam UU No. 14 tahun 2005 tentang guru dan dosen, pada pasal 20 yang di mana guru berkewajiban merencakana pembelajaran, melaksanakam proses pembelajaran yang bermutu, serta menilai dan mengevaluasi hasil pembelajaran. Selanjutnya kewajiban guru ialah mengembangkan dan meningkatkan kualifikasi akademik dan kompetensi secara berkelanjutan sejalan dengan perkembangan ilmu pengetahuan, teknologi dan seni, serta kewajiban guru ialah memelihara dan memupuk persatuan dan kesatuan bangsa dan lain sebagainya (Bambang Subiyakto \& Helmi Akmal, 2020:48).

Peran, hak, dan kewajiban guru menurut para ahli sebagai berikut :

Menurut Dr. Oemar Hamalik (2009:74) dalam bukunya psikologi belajar dan mengajar menulis peran guru. Peran guru yang pertama, ialah sebagai pengajar, salah satu 
tugas yang harus dilaksanakan oleh guru untuk memberikan pelayanan kepada siswa. Kedua, sebagai pembimbing, guru memberikan bimbingan bantuan terhadap individu untuk mencapai pemahaman dan pengarahan diri yang dibutuhkan untuk melakukan penyesuaian diri secara maksimum terhadap sekolah, keluarga dan masyarakat.

Menurut Djohar (2006:35), hak guru adalah hak untuk memperoleh gaji, hak untuk pengembangan karier, hak untuk pengembangan karier, hak untuk memperoleh kesejahteraan lain dan hak untuk memperoleh perlindungan hukum baik dalam melaksanakan tugas maupun dalam memperoleh hak-hak mereka.

Menurut pasal 20 UU R.I No. 14 Tahun 2005, kewajiban guru ialah merencakan pembelajaran, memingkatkan dan mengembangkan kualifikasi akademik, selanjutnya bertindak objektif dan tidak diskriminatif, dan menjunjung tinggi pertauran perundangundangan hukum serta memlihara dan memupuk persatuan dan kestuan bangsa (M. Yusuf Seknun, 2012:125).

\section{GURU INDONESIA DAN TANTANGAN PROFESIONALISME}

Pengertian profesionalisme adalah paham yang mengajarkan bahwa setiap pekerjaan harus dilakukan oleh orang yang profesional. Orang yang profesional yang dimaksud itu adalah orang yang memiliki profesi. Muchtar Luthfi (1984:44). Sedangkan profesionalisme guru adalah kemampuan guru dalam melakukan tugasnya sebagai seorang pengajar dan pendidik. Guru merupakan salah satu faktor utama bagi keberhasilan pendidikan. Tentunya guru yang professional memiliki kemampuan dalam melaksanakan tugas-tugas keprofessionalannya secara tepat guna dan berhasil dengan menjalankan tugas uatamanya yaitu sebagai pendidik, pengajar, pembimbing, pengarah, pelatih, penilai dan pengevaluasi siswa. Dengan adanya profesionalime pada guru maka diinginkannya tugas guru untuk memajukan pendidikan di Indonesia. Kualitas pendidikan di Indonesia terbilang masih rendah. Hal ini berarti bahwa guru harus berkewajiban mencerdaskan kehidupan bangsa menuju pembentukan manusia Indonesia seutuhnya yang berdasarkan Pancasila dan UUD 1945.

Dengan adanya profesionalisme guru maka kompetennsi profesional yang dimaksud dalam hal ini merupakan kemampuan guru menguasai materi pelajaran secara luas dan mendalam, termasuk penguasaan kemampuan akademik lainnya yang berperan sebagai pendukung profesionalisme guru. Untuk itu diharapkannya guru memiliki profesionalisme agar dapat memajukan pendidikan Indonesia (Hamid Darmadi, 2015:174).

Komponen kompetensi yang harus dimiliki guru sebagai guru professional adalah harus menguasai bahan materi ajar, kemampuan dalam mengelola pembelajaran, dan pengetahuan tentang evaluasi. Kompetensi profesional adalah kemampuan dasar yang harus dimiliki guru. Ada beberapa pandangan ahli tentang kompetensi profesional guru. Menurut Cooper (1984:15) terbagi kedalam 4 komponen kompetensi dasar yaitu : 
1). Mempunyai pengetahuan tentang belajar dan tingkah laku manusia.

2). Mempunyai pengetahuan dan menguasai bidang studi yang dibinanya.

3). Mempunyai sikap yang tepat tentang diri sendiri, sekolah, teman sejawar dan bidang studi yang dibinanya.

4). Mempunyai keterampilan dalam tehknik mengajar.

Kompetensi profesional adalah penguasaan materi pembelajaran secara luas dan mendalam, yang dimana mencakup materi kurikulum mata pelajaran di sekolahan. Dengan kata lain kompetensi profesional guru ialah kemampuan dan kewenangan guru dalam menjalankan profesinya dapat disebut sebagai guru yang kompeten dan profesional (Bambang Subiyakto \& Helmi Akmal, 2020: 63).

\section{SIMPULAN}

Berdasarkan kajian yang telah dipaparkan, maka yang dapat disimpulkan adalah pada konsep profesi guru, guru yang professional harus memiliki komitmen dan tidak boleh goyang oleh selera masyarakat, sebab tugas seorang guru untuk peserta didiknya ialah membantu opeserta didik untuk belajar, membantu dan membimbing peserta didik dalam belajar.

Guru dapat digolongkan sebagai sebuah profesi, sebab menjadi guru dituntut memiliki keahlian yang di mana akan di dapat melalui pendidikan dan latihan. Salah satunya guru adalah sebagai motivator belajar untuk peserta didik, dalam dunia pendidikan motivasi selalu menjadi faktor yang dominan dalam ikut menentukan tercapainya atau tidaknya suatu tujuan pembelajaran.

Guru sebagai sebuag profesi di bidang pendidikan yang memiliki hak dan kewajiban yang menyangkut dunia pendidikan yang digeluti. Tentunya guru yang professional memilik kemampuan dalam melaksanakan tugas-tugas keprofessionalannya secara tepat guna dan berhasil dengan menjalankan tugas utamanya yaitu sebagai pendidik, pengajar, pembimbing, pengarah, pelatih, penilai dan pengevaluasi siswa. Jadi komponen kompetensi yang harus dimiliki guru sebagai guru professional adalah harus menguasai bahan materi ajar, kemampuan dalam mengelola pembelajaran, dan pengetahuan tentang evaluasi.

\section{REFERENSI}


Efendi, I., Prawitasari, M., \& Susanto, H. (2021). Implementasi Penilaian Pembelajaran Pada Kurikulum 2013 Mata Pelajaran Sejarah. Prabayaksa: Journal of History Education, 1(1), 21-25.

Susanto, H. (2020). Profesi Keguruan. Banjarmasin: FKIP Universitas Lambung Mangkurat.

Susanto, H., \& Akmal, H. (2018). Efektivitas Penggunaan Aplikasi Pembelajaran Berbasis Mobile Smartphone Sebagai Media Pengenalan Sejarah Lokal Masa Revolusi Fisik Di Kalimantan Selatan Pada Siswa Sekolah Menengah Atas. HISTORIA: Jurnal Program Studi Pendidikan Sejarah, 6(2), 197-206.

Susanto, H., Irmawati, I., Akmal, H., \& Abbas, E. W. (2021). Media Film Dokumenter Masuknya Islam Ke Nusantara dan Pengaruhnya Terhadap Keterampilan Berpikir Kritis Siswa. HISTORIA: Jurnal Program Studi Pendidikan Sejarah, 9(1).

Syaharuddin, S., \& Susanto, H. (2019). Sejarah Pendidikan Indonesia (Era Pra Kolonialisme Nusantara sampai Reformasi). Banjarmasin: FKIP Universitas Lambung Mangkurat.

Syarnubi, S. (2019). Guru yang bermoral dalam konteks sosial, budaya, ekonomi, hukum dan agama (Kajian terhadap UU No 14 Tahun 2005 Tentang Guru Dan Dosen). Jurnal PAI Raden Fatah, 1(1), 21-40.

Hamid, A. (2017). Guru Profesional. Al-Falah: Jurnal Ilmiah Keislaman dan Kemasyarakatan, 17(2), 274-285.

Darmadi, H. (2016). Tugas, peran, kompetensi, dan tanggung jawab menjadi guru profesional. Edukasi: Jurnal Pendidikan, 13(2), 161-174.

Komara, E. (2016). Perlindungan Profesi Guru di Indonesia. Mimbar Pendidikan, 1(2).

Manizar, E. (2015). Peran guru sebagai motivator dalam belajar. Tadrib, 1(2), 204-222.

Mudhofir, A. (2012). Pendidik profesional: konsep, strategi, dan aplikasinya dalam peningkatan mutu pendidikan di Indonesia.

Kartowagiran, B. (2011). Kinerja guru profesional (Guru pasca sertifikasi). Jurnal Cakrawala Pendidikan, 3(3).

Gaffar, M. F. (2007). Guru Sebagai Profesi. Jurnal Administrasi Pendidikan, 5(1).

Muhson, A. (2004). Meningkatkan Profesionalisme Guru: Sebuah Harapan. Jurnal Ekonomi dan Pendidikan, 1(2). 